\title{
Information and Communication Technologies (ICTs) Adoption by MSMEs and Local Poverty: An Empirical Evidence from Indonesia
}

\author{
Dewi Hanggraeni \\ Department of Management, Faculty of Economics and Business, Universitas Indonesia \\ *Corresponding Author: dewi.hanggraeni@ui.ac.id
}

\begin{abstract}
This paper aims to examine a relationship between the adoption of Information and Communication Technologies (ICTs) by Micro, Small, and Medium Enterprises (MSMEs) and local poverty in Indonesia. Previous literature has shown that the adoption of ICTs is a significant catalyst to increasing a nation's productivity from a macroeconomic perspective. This has imposed a new debate among researchers whether the adoption of ICTs can contribute to a more specific economic development goal: reducing poverty. Some researchers argue that the means of a broader economic development can be obtained through the informal sectors, MSMEs. Therefore, this paper argues that in order to find a more satisfactory result, the role of ICTs adoption in reducing poverty needs to be examined from within a more specific economic agent - the MSMEs. To test the hypothesis, we run OLS regression models with province and year fixed effects on our MSMEs survey data and local poverty measures. The results show a robust, negative relationship between the adoption of ICTs by MSMEs and the number of poor populations in the corresponding region, controlling other factors.
\end{abstract}

Keywords: ICTs; Indonesia; MSMEs; Poverty; Regional Economics

\section{INTRODUCTION}

Recent evidence tells us that the adoption of Information and Communication Technology (ICTs) is a vital driver to increase economic activities and productivity in both developed and developing countries (Cardona et al., 2013; Dedrick et al., 2013; Jorgenson \& Vu, 2016; Paunov \& Rollo, 2016; Stanley et al., 2018; World Bank, 2016). However, what do these findings imply to answering one of the major economic problems: economic inequality, specifically towards poverty? This question was first raised by Adeya (2002) with a concern of clear evidence showing the impact of ICTs on poverty. Adera et al. (2014) further argue that these benefits from adopting ICTs are not automatic, and its contribution to reducing poverty has yet existed.

The main concern with these studies is the fact of corporates or industrialized sectors as the basic assumption for IT investment. Consequently, these findings cannot explain any 
contribution to income inequality as though the increasing number of outputs in the economy might benefit social welfare in general, but aren't the main economic players the most benefited from this? And therefore, there is a possibility of a further gap in income inequality from the adoption of ICTs. Several studies (such as Abraham, 2005; Chew et al., 2010; Donner \& Escobari, 2010) have provided an implication of economic growth from ICTs adoption to contribute as an income generator for low-income communities; however, a robust relationship is yet found. Therefore, some countries may not receive the same benefits from investing highly on ICTs. Mpogele et al. (2008) even suggest that ICTs in lowincome countries may represent an excess of cost rather than economic benefit. Besides, the fact that ICTs adoption might lead to mass unemployment remains relevant to this day (Brynjolfsson \& McAfee, 2014; Peng, Wang, \& Han, 2018; Van Roy et al., 2018). Examining it from within the macroeconomic point of view might impose bias for which large enterprises are usually skill-labor oriented, and therefore ICTs adoption would eventually further deviate the number of unemployment and poor population.

From that perspective, examining the role of ICTs from within informal sectors as the main economic actors in developing countries - especially rural areas - might shed some light to this question. Chacko and Harris (2006) argue that ICTs adoption by MSMEs to participate in the knowledge economy offers opportunities to narrow social and economic inequalities and thus help achieve broader development goals. Furthermore, the fact that MSMEs continue contributing more to the economy affirms that the informal sectors are the most prominent as a means of poverty reduction. Therefore, to answer how ICTs adoption contributes to reducing poverty, examining it from within MSMEs is appropriate. However, note that it is plausible only if institutional quality and level of development are satisfied (Dell'Anno \& Solomon, 2014). This paper provides a new finding of a direct relationship between the adoption of ICTs within MSMEs and the number of local poverty in Indonesia.

\section{HYPOTHESES DEVELOPMENT}

The role of MSMEs in the Indonesian economy itself has always been significant, especially for low-income households in rural areas (Tambunan, 2007). According to the Indonesia Statistics Bureau (2019), MSMEs account for 98.68 percent of the economy, contributing around 61.41 percent to total outputs. However, a larger number of MSMEs and the fact they contribute more to total outputs do not necessarily mean less poverty. As found in Beck et al. (2005), even though MSMEs might benefit economic growth for some specific countries, there is no particular beneficial impact on the incomes of the poor. Nevertheless, the role of MSMEs in reducing poverty remains potential. Meryana (2012) argues that MSMEs in Indonesia have an eminence for broader economic development in a way they mostly produce basic-necessity products and absorb more than 75 percent of employment. Furthermore, looking at the ratio of gender within the economy (IFC, 2016), women generally account more in the informal sectors. This implies that MSMEs can accommodate what large enterprises are unable to do: equality.

Although several empirical evidence for ICTs adoption within MSMEs in contributing to the economy exist (Botelho \& da Silva Alves, 2007; Heeks, 2010; Ismail et al., 2011; Nielinger, 2003), most of them discuss the adoption of ICTs in increasing MSME's productivity and therefore increasing total outputs in the economy. Of course, some of these findings imply the potential in poverty reduction in a way it offers opportunities for the poor and provision of social benefits (Duncombe, 2007), however, a straightforward 
relationship is inadequate. This paper contributes to the literature by offering a robust, direct relationship between ICTs adoption by MSMEs and the number of poor populations in Indonesia.

ICTs refer to any artifact, technique, or knowledge used for capturing, storage, processing, and dissemination of information (Duncombe \& Heeks, 2002), which include, among others, television, radio, telephones, fax, computers, and the internet (Marker et al., 2002). In this research, ICTs refer to the use of the internet which includes the use of social media and e-commerce. To indicate how ICTs are used in MSMEs, a survey was conducted on the MSME's owners within five different provinces in Indonesia. Using simple regression, this indicator is then tested against the number of poor populations in each province. Based on the above reviews of previous literature and the gap in empirical evidence between the employment of ICTs within MSMEs and Local Poverty in Indonesia, this research proposes the following hypothesis:

H1: The more active MSMEs adopt ICTs in their business, the fewer poor people in the corresponding region.

\section{METHOD, DATA, AND ANALYSIS}

\section{Methodology}

To test the hypothesis, a simple regression is used with the 2011-2020 year and province dummies (Cameron \& Trivedi, 2019; Niebel, 2018; Lee et al., 2011). The province dummy is employed to control for time-invariant differences in long-run changes due to unexplained factors that differ across provinces, while the time dummy is to control for the MSME's business cycle (Jayaratne \& Strahan, 1996). For the indicator of ICTs adoption, a survey was conducted by means of a structured questionnaire on a 5-point Likert scale with 1-as least active and 5-as very active. There are four items used to explain the adoption of ICTs within MSMEs (Table 1).

A composite index of ICTs adoption within MSMEs is developed using a principal component approach (OECD, 2008). The principal component then provides a continuous variable from the ordinal nature of the questionnaire responses. Other than the use of social media and e-commerce, MSMEs were asked about their participation with large enterprises and the local government as well. This is to capture the skeptical views in which they argue that MSMEs have less both knowledge and financial capital to exploit the positive effects of ICTs adoption towards a broader economic development (Beck et al., 2005). By actively participating with large enterprises and local government, it can arguably resolve such issue. As for the dependent variable, local poverty is indicated by the logarithm of the number of poor people to total population in each region.

As control variables, several economic indicators are employed in the regression. First, regional inflation is employed to control the fact that inflation affects the number of poor populations in the corresponding region. When the economy experiences inflation, fewer people will be able to satisfy their necessities, and therefore producing more poor populations in the economy. This indicator is necessary to control the statistical results should the inflation aspect varies for MSMEs in different regions. Second, logarithm of the number of total populations in the corresponding region is employed to control the fact that more population can mean more poor people. Lastly, some MSMEs' financial performance indicators are also employed in the regression. This is to control the fact that the contribution of ICT adoption by MSMEs towards reducing poverty might differ based 
on their financial performance. Overall, the main model for this research is mathematically written in the following equation (1).

$$
\begin{aligned}
& \text { lnpoort }=\beta_{0}+\beta_{1} p c_{-} I T T+\beta_{2} \text { infl }+\beta_{3} \text { lnpop }+\beta_{4} m u_{-} R O A+\beta_{5} m u_{-} T R t A+ \\
& \beta_{6} \ln \_ \text {mu_Tasset }+ \text { yrfe }+ \text { provfe }+\mu
\end{aligned}
$$

\begin{tabular}{|c|c|c|c|c|c|c|}
\hline \multirow{2}{*}{ No. } & \multirow{2}{*}{ Items } & \multirow{2}{*}{ Code } & \multicolumn{4}{|c|}{ Principal Component Scores } \\
\hline & & & Comp. 1 & Comp. 2 & Comp. 3 & Comp. 4 \\
\hline 1. & $\begin{array}{l}\text { How active do you use technology, } \\
\text { specifically social media such as } \\
\text { Facebook and Instagram for product } \\
\text { marketing activities? }\end{array}$ & ITT1 & 0.4903 & 0.6562 & 0.4136 & 0.3975 \\
\hline 2. & $\begin{array}{l}\text { How active do you utilize e- } \\
\text { commerce such as Tokopedia, } \\
\text { Bukalapak, and Lazada for product } \\
\text { marketing compared to your } \\
\text { competitors? }\end{array}$ & ITT2 & 0.5044 & 0.2933 & -0.7386 & -0.3378 \\
\hline 3. & $\begin{array}{l}\text { How active do you and your } \\
\text { employees participate in training } \\
\text { related to mastery of technology? }\end{array}$ & ITT3 & 0.5089 & -0.3219 & 0.5032 & -0.6198 \\
\hline 4. & $\begin{array}{l}\text { How active do you participate in } \\
\text { mentoring related to the application } \\
\text { of technology held by the government } \\
\text { and/or large enterprises compared to } \\
\text { your competitors? }\end{array}$ & ITT4 & 0.4962 & -0.6163 & -0.1740 & 0.5862 \\
\hline
\end{tabular}

Table 1. Principal Component Analysis

For the robustness check, an alternative measurement for the dependent variable and the main regressor is employed in the model. As for the robust-check dependent variable, local poverty is defined as the ratio of poor people to total populations in the corresponding region. And as for the indicator of ICTs adoption, a weighted sum approach is employed to obtain the composite index. Therefore, for the robustness check, the following regression model is employed in equation (2).

$$
\begin{aligned}
& \text { poorrat }=\beta_{0}+\beta_{1} m u_{-} I T T+\beta_{2} \text { infl }+\beta_{3} \operatorname{lnpop}+\beta_{4} m u_{-} R O A+\beta_{5} m u_{-} T R t A+ \\
& \beta_{6} \ln \_m u_{-} T a s s e t+y r f e+p r o v f e+\mu \\
& \text { poorrat }=\text { The ratio of poor people to total population }
\end{aligned}
$$


mu_ITT = Weighted sum composite index of ICTs adoption by MSMEs

\section{The Data}

This paper utilizes both primary and secondary data for the regression. As for the primary data, we obtained a one-time survey data conducted to by means of a structured questionnaire to micro, small, and medium scale enterprises (MSMEs). In this study, MSMEs are defined according to the Law No. 20/2008. First, Micro Enterprises are defined to have a maximum of IDR50 million of total assets. Second, Small Enterprises are defined to have a range of total assets from IDR 50 - 500 million. and lastly, Medium Enterprises are defined to have a range of total assets from IDR 500 million to IDR 10 billion. The analysis is performed on a municipal-scale of observation. Since the data for main regressor was obtained from a one-time survey data, an analysis at district-level would impose collinearity. Therefore, a simple regression with province dummies is employed by average to obtain an appropriate result (Cameron \& Trivedi, 2019). The sampling method used is convenient sampling, that is regions which provide the most available data for the researchers. The sample consists of 1401 MSMEs from five different provinces in Indonesia, namely East Java, East Nusa Tenggara, West Nusa Tenggara, North Sumatra, and West Sumatra. The number of MSMEs for the sample in this research is summarized in Table 2., consisting of two panels. The first panel describes the number of MSMEs by province, and the second panel describes the number of MSMEs by business sector. The respondents in this study are the MSMEs owners to answer the four main questions mentioned in Table 1. Province and year dummies are employed to the survey data, constructing 100 total observations into the main regression, as summarized in Table 3.

Table 2. The Sample Number of MSMEs by Province and by Business Sector

Panel A. Number of MSMEs by Province

\begin{tabular}{clccc}
\hline No. & Province & $\begin{array}{c}\text { Number of } \\
\text { Municipals } \\
\text { Observed }\end{array}$ & $\begin{array}{c}\text { Number of } \\
\text { MSMEs in The } \\
\text { Sample }\end{array}$ \\
\hline 1. & East Java & 3 & 401 \\
2. & East Nusa Tenggara & 2 & 300 \\
3. & West Nusa Tenggara & 3 & 300 \\
4. & North Sumatera & 1 & 200 \\
5. & West Sumatera & 1 & 200 \\
\cline { 3 - 4 } & & Total & $\mathbf{1 0}$ & $\mathbf{1 4 0 1}$ \\
\hline
\end{tabular}

Panel B. Number of MSMEs by Business Sector

\begin{tabular}{|c|c|c|}
\hline No. & Business Sector & Number MSMEs in The Sample \\
\hline 1. & Manufacture & 104 \\
\hline 2. & Services & 177 \\
\hline 3. & Trade, hotel \& restaurant & 1097 \\
\hline \multirow[t]{2}{*}{4.} & Others & 23 \\
\hline & Total & 1401 \\
\hline
\end{tabular}


Table 3. Observation Structure in The Main Regression

Panel A. Number of Observations by Province Dummy

\begin{tabular}{|c|c|c|}
\hline No. & Province Dummy & Total Observations \\
\hline 1. & East Java & 30 \\
\hline 2. & East Nusa Tenggara & 20 \\
\hline No. & Province Dummy & Total Observations \\
\hline 3. & West Nusa Tenggara & 30 \\
\hline 4. & North Sumatera & 10 \\
\hline \multirow[t]{2}{*}{5.} & West Sumatera & 10 \\
\hline & Total & 100 \\
\hline \multicolumn{3}{|c|}{ Panel B. Number of Observations by Year Dummy } \\
\hline No. & Year Dummy & Total Observations \\
\hline 1. & 2011 & 10 \\
\hline 2. & 2012 & 10 \\
\hline 3. & 2013 & 10 \\
\hline 4. & 2014 & 10 \\
\hline 5. & 2015 & 10 \\
\hline 6. & 2016 & 10 \\
\hline 7. & 2017 & 10 \\
\hline 8. & 2018 & 10 \\
\hline 9. & 2019 & 10 \\
\hline \multirow[t]{2}{*}{10.} & 2020 & 10 \\
\hline & Total & 100 \\
\hline
\end{tabular}

As for the economic indicators, this research utilizes data from the Indonesia Statistics Bureau archive to obtain the number of poor people and the total population in each province, as well as the inflation in each province for the year 2011-2020. The descriptive statistics of this research are summarized as follows.

Table 4. Descriptive Statistics

\begin{tabular}{clcccccc}
\hline No. & Variable & $\mathbf{N}$ & Mean & SD & CV & Min & Max \\
\hline 1. & poorp & 94 & $110,978.3$ & $55,213.81$ & 0.50 & 6,000 & 209,690 \\
2. & lnpoor & 94 & 11.34 & 0.98 & 0.09 & 8.70 & 12.25 \\
3. & poorrat & 94 & 0.14 & 0.07 & 0.50 & 0.05 & 0.31 \\
4. & pc_ITT & 100 & -0.11 & 1.07 & -9.73 & -2.24 & 1.18 \\
5. & mu_ITT & 100 & 2.24 & 0.57 & 0.25 & 1.10 & 2.92 \\
6. & mu_ITT1 & 100 & 2.29 & 0.60 & 0.26 & 1.11 & 2.92 \\
7. & mu_ITT2 & 100 & 2.16 & 0.59 & 0.27 & 1.07 & 2.89 \\
8. & mu_ITT3 & 100 & 2.25 & 0.55 & 0.24 & 1.12 & 2.92 \\
9. & mu_ITT4 & 100 & 2.25 & 0.58 & 0.26 & 1.11 & 2.98 \\
10. & mu_infl & 90 & 0.05 & 0.03 & 0.60 & -0.05 & 0.18 \\
11. & pop & 94 & $959,890.1$ & $709,807.9$ & 0.74 & 113,903 & $2,295,003$ \\
12. & lnpop & 94 & 13.46 & 0.87 & 0.06 & 11.64 & 14.64 \\
13. & mu_ROA & 100 & 1.37 & 1.28 & 0.93 & 0.18 & 3.98 \\
14. & mu_TAtR & 100 & 13.76 & 28.97 & 2.11 & 1.49 & 99.93 \\
15. & mu_Tasset & 100 & $57,900,000$ & $49,600,000$ & 0.86 & $6,373,771$ & $193,000,000$ \\
16. & ln_mu_Tasset & 100 & 17.56 & 0.84 & 0.05 & 15.67 & 19.08 \\
\hline
\end{tabular}


The descriptive statistics (Table 4.) show that the ratio of poor people to total population is around $14 \%$ in five provinces outside Jakarta. This is higher than the ratio of poor people to total population nationally which is recorded at $9.78 \%$ and even much higher than the ratio of poor people to total population in Jakarta which is recorded at $3.42 \%$ (Indonesia Statistics Bureau, 2020). This confirms an unequal wealth distribution in Indonesia. From this research's sample alone, there is quite a dispersion in poor population ratio among the five provinces. The lowest ratio recorded in this research's sample is at 5\%, while the highest ratio is $31 \%$. Nevertheless, poverty has been gradually reduced, at least since 2007 the number of the national poor population was recorded around $17.7 \%$ of the total population. The Pro-Poor Planning and Budgeting Project (2008) notes that micro and small enterprises had a significant role in poverty reduction since the income generator for most individuals or poor families, specifically in rural areas, is by establishing a micro or small enterprise, making MSMEs the most prominent agent of wealth distribution in Indonesia. Additionally, this type of enterprise absorbs more labor from poor families since it requires lower qualities of human capital. These enterprises are significant for poor communities in providing jobs and producing the outputs that poor people consume (Meryana, 2012). Therefore, even though the role of MSMEs does not necessarily contribute to increasing the income of the poor, MSMEs contribute to reducing the number of poor people through employment and affordable consumption goods.

In the literature, ICTs adoption contributes to the economy in a way it offers more productivity. If more MSMEs actively exploit the benefits of ICTs adoption, it should make sense that more affordable outputs are produced in the economy and eventually leads to more job creation for the poor. However, the descriptive statistics show that MSMEs' total asset to revenue is very dispersed, indicating a great variance in MSME's ability in exploiting its asset to generate revenues. An MSME might generate over 99 units of revenue from one unit of its asset, while the other only generates a little over one unit of revenue from one unit of its asset. On average, MSMEs in Indonesia generate around 13 units of revenue from one unit of asset. This implies that for some MSMEs, ICTs investment might rather lead to excess cost than its supposed benefits, which confirms the skeptical views towards MSMEs (Beck et al., 2005). This is an important key to consider when examining the benefits of ICTs adoption by MSMEs towards reducing poverty. If ICTs adoption is only measured by how much MSMEs invest in ICTs, it might produce an unsatisfactory result.

\section{RESULTS}

Table 5. shows the main regression results in which six simple regressions were estimated. Model 1 includes only the main regressor for ICTs adoption by MSMEs. Without other variables controlling, the result shows that ICTs adoption within MSMEs cannot significantly explain the number of poor people within its region. Model 2-6 adds the control variables into the regression one at a time. First, in Model 2, the result shows that when incorporated with inflation, neither the ICTs adoption within MSMEs nor inflation can significantly explain the number of poor people within its region. Throughout all the models, we see that as though there is a positive relationship between inflation and local poverty, inflation itself cannot significantly explain the number of poor population in each region. When total population is incorporated in the regression (Model 3), we see that both ICTs adoption within MSMEs and total population significantly explain the number of poor populations in the corresponding region. Model 3 shows a significant negative relationship between ICTs adoption within MSMEs and local poverty when inflation and total 
population are incorporated, while total population itself has a significant positive relationship with local poverty. In Model 4 and Model 5, we see that when return on asset and asset turnover are incorporated in the regression, ICTs adoption within MSMEs has a significant negative relationship with local poverty and the coefficient decreases greatly. This confirms the difference in the adoption of ICTs within MSMEs' contribution to reducing poverty when MSME's ability in exploiting its ICTs asset effectively is incorporated. Finally, in model 6, the results show that when all variables controlling, an increase in ICTs adoption by MSMEs leads to a significant decrease in the number of poor people in the population. Overall, this result shows a good-fitting model with $99.6 \%$ of Rsquare at 0.000 significance.

Table 5. Regression Results

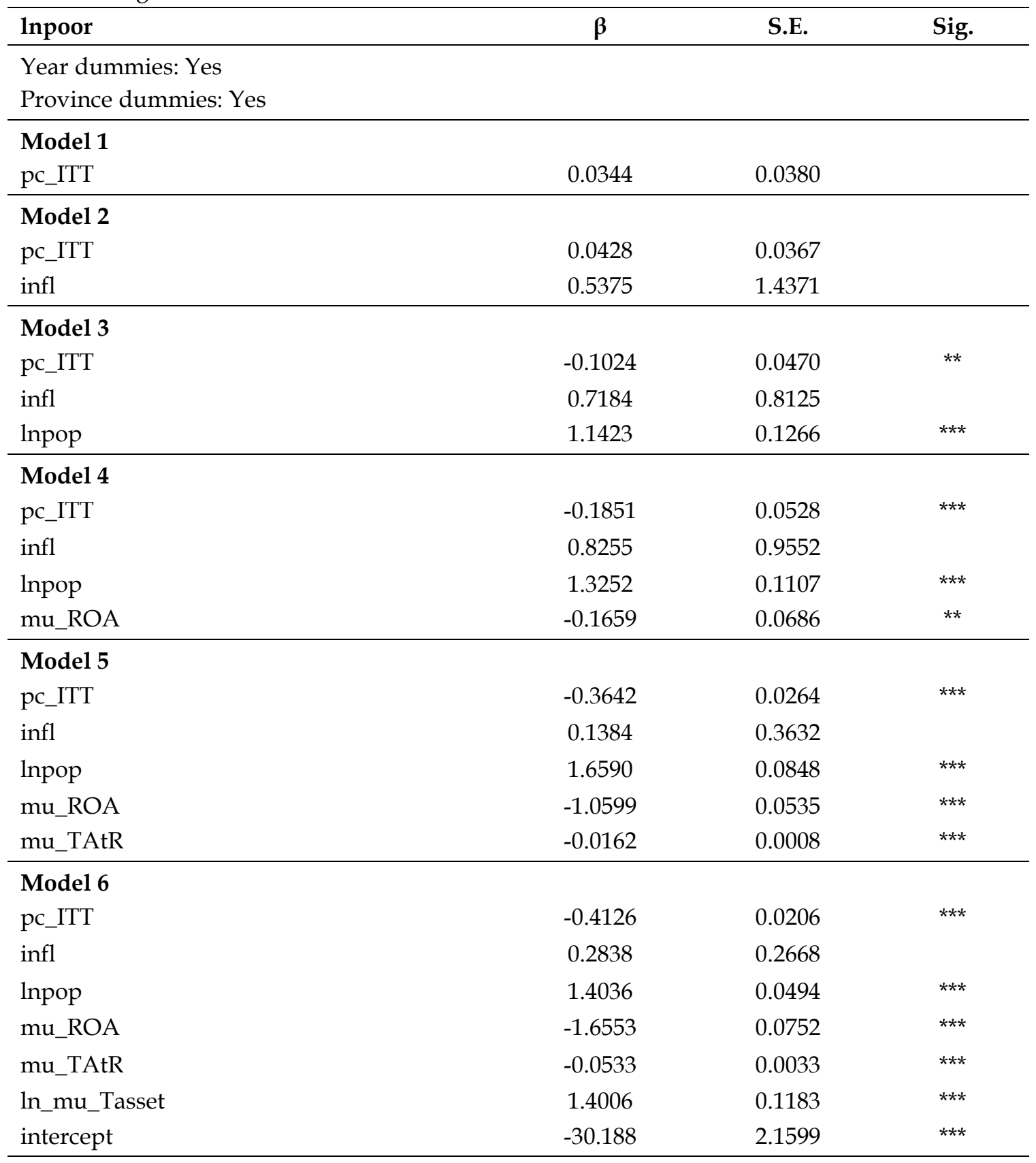




\begin{tabular}{lccc}
\hline lnpoor & $\boldsymbol{\beta}$ & S.E. & Sig. \\
\hline Number of obs & 87 & & \\
F $(19,67)$ & 1793.40 & & \\
Prob $>$ F & 0.0000 & & \\
R-squared & 0.9956 & & \\
Root MSE & 0.0759 & & \\
\hline
\end{tabular}

Note: $* * *$, and ${ }^{* * *}$ indicate variable significance at $0.1,0.05$, and 0.01 , respectively.

Next, turning to the robustness check, the regression incorporates a different measuring approach for ICTs adoption by MSMEs and local poverty. For ICTs adoption, the composite index is estimated using a weighted sum approach, and local poverty is measured with the ratio of poor people to total populations in each corresponding region. The result provides a good-fitting model with $97.0 \%$ of R-square at 0.000 significance. This model provides the same result in which when all variables controlling, ICTs adoption by MSMEs and local poverty have a significant negative relationship. This confirms the robustness in the relationship between ICTs adoption by MSMEs and local poverty, which implies that the benefit of ICTs adoption within MSMEs is possible for every region in Indonesia. The result of this model is summarized in Table 6.

Table 6. Robustness Check

\begin{tabular}{lccc}
\hline poorrat & $\boldsymbol{\beta}$ & S.E. & Sig. \\
\hline Year fixed effect: Yes & & & \\
Province fixed effect: Yes & & & \\
\hline mu_ITT & -0.0467 & 0.0030 & $* * *$ \\
Infl & 0.0538 & 0.0593 & \\
lnpop & 0.0505 & 0.0086 & $* * *$ \\
mu_ROA & -0.1889 & 0.0131 & $* * *$ \\
mu_TAtR & -0.0071 & 0.0007 & $* * *$ \\
ln_mu_Tasset & 0.1984 & 0.0259 & $* * *$ \\
intercept & -3.8091 & 0.4016 & $* * *$ \\
\hline Number of obs & 87 & & \\
F (19,67) & 208.20 & & \\
Prob $>$ F & 0.0000 & & \\
R-squared & 0.9702 & & \\
Root MSE & 0.0144 & & \\
\hline
\end{tabular}

Note: ${ }^{* *}$, and ${ }^{* * *}$ indicate variable significance at $0.1,0.05$, and 0.01, respectively.

Lastly, this paper provides a decomposition of the contribution of each item constructing the variable ICTs adoption by MSMEs to local poverty. Item 1 and 2 explain how active the MSME adopts social media and e-commerce in its business, respectively. Item 3 and 4 explain how active the MSME participates in an ICTs mastery and how active the MSME participates in training provided by large enterprises and local government. The result is shown in Table 7. Both using Inpoor and poorrat, the result implies that the most important factor in ICTs adoption is item 4 which explains MSMEs' participation in ICTs training provided by large enterprises and local government. Followed by item 3 which explains MSMEs' participation in ICTs mastery. Between social media and e-commerce, the 
result shows that the use of e-commerce contributes more to decreasing local poverty than social media.

Table 7. Decomposition of ICTs Adoption by MSMEs and Local Poverty

\begin{tabular}{|c|c|c|c|c|c|c|c|}
\hline \multicolumn{4}{|c|}{ Model 1} & \multicolumn{4}{|c|}{ Model 2} \\
\hline lnpoor & $\beta$ & S.E. & Sig. & poorrat & $\beta$ & S.E. & Sig. \\
\hline mu_ITT1 & -0.5488 & 0.0269 & $* * *$ & mu_ITT1 & -0.0622 & 0.0039 & $* * *$ \\
\hline infl & 0.2819 & 0.2719 & & infl & 0.0535 & 0.0599 & \\
\hline $\operatorname{lnpop}$ & 1.3335 & 0.0465 & $* * *$ & lnpop & 0.0426 & 0.0083 & $* * *$ \\
\hline mu_ROA & -1.2846 & 0.0599 & $* * *$ & mu_ROA & -0.1470 & 0.0112 & $* * *$ \\
\hline mu_TRtA & -0.0412 & 0.0029 & $* * *$ & mu_TRtA & -0.0057 & 0.0007 & $* * *$ \\
\hline ln_mu_Tasset & 1.0820 & 0.1087 & $* * *$ & ln_mu_Tasset & 0.1623 & 0.0248 & $* * *$ \\
\hline Intercept & -22.8987 & 1.8599 & $* * *$ & intercept & -2.9836 & 0.3660 & $* * *$ \\
\hline mu_ITT2 & -0.6251 & 0.0307 & $* * *$ & mu_ITT2 & -0.0708 & 0.0044 & $* * *$ \\
\hline Infl & 0.2821 & 0.2713 & & infl & 0.0536 & 0.0598 & \\
\hline $\operatorname{lnpop}$ & 1.3416 & 0.0468 & $* * *$ & $\operatorname{lnpop}$ & 0.0435 & 0.0083 & $* * *$ \\
\hline mu_ROA & -1.5233 & 0.0690 & $* * *$ & mu_ROA & -0.1740 & 0.0124 & $* * *$ \\
\hline mu_TRtA & -0.0548 & 0.0034 & $* * *$ & mu_TRtA & -0.0073 & 0.0007 & $* * *$ \\
\hline ln_mu_Tasset & 1.5232 & 0.1213 & $* * *$ & ln_mu_Tasset & 0.2123 & 0.0263 & $* * *$ \\
\hline intercept & -30.1791 & 2.1351 & $* * *$ & intercept & -3.8084 & 0.3994 & $* * *$ \\
\hline mu_ITT3 & -1.0246 & 0.0522 & $* * *$ & mu_ITT3 & -0.1160 & 0.0075 & $* * *$ \\
\hline infl & 0.2859 & 0.2612 & & infl & 0.0540 & 0.0587 & \\
\hline $\operatorname{lnpop}$ & 1.4814 & 0.0530 & $* * *$ & lnpop & 0.0593 & 0.0089 & $* * *$ \\
\hline mu_ROA & -1.9981 & 0.0915 & $* * *$ & mu_ROA & -0.2278 & 0.0152 & $* * *$ \\
\hline mu_TRtA & -0.0579 & 0.0035 & $* * *$ & mu_TRtA & -0.0076 & 0.0007 & $* * *$ \\
\hline ln_mu_Tasset & 1.4328 & 0.1204 & $* * *$ & ln_mu_Tasset & 0.2020 & 0.0261 & $* * *$ \\
\hline intercept & -29.0967 & 2.1470 & $* * *$ & intercept & -3.6851 & 0.3990 & $* * *$ \\
\hline mu_ITT4 & -1.2291 & 0.0643 & $* * *$ & mu_ITT4 & -0.1392 & 0.0092 & $* * *$ \\
\hline Infl & 0.2884 & 0.2546 & & infl & 0.0543 & 0.0580 & \\
\hline lnpop & 1.5746 & 0.0577 & $* * *$ & $\operatorname{lnpop}$ & 0.0699 & 0.0094 & $* * *$ \\
\hline mu_ROA & -2.2554 & 0.1056 & $* * *$ & mu_ROA & -0.2569 & 0.0170 & $* * *$ \\
\hline mu_TRtA & -0.0697 & 0.0041 & $* * *$ & mu_TRtA & -0.0090 & 0.0008 & $* * *$ \\
\hline ln_mu_Tasset & 1.7682 & 0.1336 & $* * *$ & ln_mu_Tasset & 0.2400 & 0.0276 & $* * *$ \\
\hline intercept & -35.2998 & 2.4501 & $* * *$ & intercept & -4.3872 & 0.4350 & $* * *$ \\
\hline
\end{tabular}

Note: $* * *$, and ${ }^{* * *}$ indicate variable significance at $0.1,0.05$, and 0.01 , respectively.

\section{DISCUSSION}

The result of this research shows a robust, negative relationship between ICTs adoption by MSMEs and local poverty, however, only when all variables controlling. Specifically, the result implies that the significance in ICTs adoption contributing to reducing poverty can be greatly enhanced if MSMEs' return on asset and asset turnover are incorporated. This rather confirms the skeptical views towards MSMEs in which they argue MSMEs do not have both the knowledge and financial capital to obtain the satisfactory benefit from ICTs adoption and would rather lead to excess cost (Beck et al., 2005). This highlights the result in Table 7. in which the most important factor in ICTs adoption within MSMEs is to actively participate in training related to ICTs mastery (item 3 and 4) so that 
MSMEs can optimally exploit the benefit of ICTs asset into generating revenues. Interestingly, the result in Model 6, Table 5. shows that an increase in one unit of total asset increases 1.4 of poor population ratio exponentially. This implies that when MSMEs grow bigger, the ratio of poor population will increase as well. This is because when an enterprise grows bigger, it becomes more skilled-labor oriented. Furthermore, when the MSMEs finally obtain the efficiency and productivity benefits from adopting ICTs, they would rather invest more in ICTs asset than hiring more employees. Therefore, the concern of mass employment from adopting ICTs is relevant in the informal sectors as well.

This paper also provides an explanation of MSMEs' financial performance towards reducing local poverty. The result shows that when all variables are incorporated, a oneunit increase in MSMEs' return on asset decreases 1.66 units of the ratio of poor population exponentially, while a one-unit increase in MSMEs' asset turnover decreases 0.05 unit of the ratio of poor population exponentially. This result implies that Indonesia's economic development can be obtained if MSMEs can perform well in the economy.

Next, turning to the results in Table 7. it implies that the most important factors in ICTs adoption in MSMEs are item 3 and item 4. This suggests that more training related to ICTs implementation should be easily available and affordable for MSMEs in every region in Indonesia. This also suggests that the benefits of ICTs adoption in MSMEs can contribute more to economic development if large enterprises cooperate highly with MSMEs. This makes sense since large enterprises can provide both the knowledge and financial capital for MSMEs which they do not have, while MSMEs provide a better and more equal wealth distribution for which large enterprises are unable to do.

Between social media and e-commerce, the result shows that e-commerce adoption by MSMEs contributes more than the adoption of social media. This makes sense since ecommerce provides an easy and reachable marketplace between sellers and buyers, and therefore more products are easily available for the poor communities than the conventional marketplace. Furthermore, e-commerce usually provides a lower price for goods and services than the conventional marketplace for various reasons. Therefore, the adoption of e-commerce in MSMEs provides more affordable goods and services to the poor communities.

\section{CONCLUSION, LIMITATIONS, AND SUGGESTIONS}

\section{Conclusion}

This paper aims to find a direct relationship between ICTs adoption by MSMEs and local poverty in which the results show a significant negative relationship. However, this relationship can only be obtained if other variables are controlling, specifically if both MSMEs' return on asset and asset turnover are employed in the regression, ICTs adoption within MSMEs' contribution to reducing poverty can be greatly enhanced. This suggests that the benefits of adopting ICTs within MSMEs' can contribute to local poverty greatly if MSMEs can exploit the efficiency and productivity benefits from adopting ICTs in their business. This rather confirms the argument by (Mpogele et al., 2008) in which the adoption of ICTs in the poor-income region would rather lead to excess cost than its economic benefits. This is due to MSMEs' lack of knowledge and financial capital in exploiting the positive effects of ICTs into a broader economic development (Beck et al., 2005). This is proven by the result in Model 1 (Table 5.) which shows when the indicator of ICTs adoption by MSMEs alone is employed, the regression produces a non-significant relationship to local poverty. If adopting ICTs only leads to an excess cost, the significant role of MSMEs 
for the poor communities is no longer relevant for which they cannot provide more jobs and produce the affordable goods and services that the poor people consume (Meryana, 2012). Interestingly, this paper finds a positive relationship between MSMEs' size and local poverty. This suggests that when MSMEs grow bigger in size, they become more skilledlabor oriented, and therefore their role in providing jobs for the poor communities is no longer relevant. Furthermore, this result suggests that the concern of ICTs adoption leading to mass unemployment is relevant in MSMEs as well. Nevertheless, this paper shows the prominent role of MSMEs in wealth distribution for the poor in Indonesia can be enhanced by adopting ICTs in their business. Table 7 . suggests a necessity for more available and affordable training related to employing ICTs in their business, so that MSMEs can obtain the efficiency and productivity benefits from adopting ICTs.

\section{Limitation and suggestions}

This paper contributes to the literature by providing an empirical direct relationship between the adoption of ICTs within MSMEs and local poverty in Indonesia. However, this paper has a limitation for which it cannot provide the process of how MSMEs being more active in adopting ICTs can lead to less local poverty. Further research should be conducted to support the findings in this paper and with more samples to better explain the population. Specifically, this paper cannot provide an explanation of whether the adoption of ICTs by MSMEs can lead to less local poverty by enabling them produce more affordable goods and services for the poor or by providing more jobs that do not require high-quality labors. Another limitation of this research that needs to be mentioned is the convenient sampling method used to explain the relationship. Note however, that according to data in Bank Indonesia (2021), the proportion of this research's sample in MSME's credit exceeds one fifth of the total MSME's credit in Indonesia. Therefore, the sample in this research can arguably explain the total population. This research cannot provide a more in-depth analysis at district-level analysis due to the nature of the data. Also, a cross-country analysis should be conducted to find a more robust result on whether the use of ICTs in MSMEs can decrease a nation's poverty.

\section{REFERENCES}

Abraham, R. (2005). Mobile phones and economic development: Evidence from the fishing industry in India. (Ph.D.). Columbia University, Ann Arbor. Retrieved from https:// search.proquest.com/dissertations-theses/mobile-phones-economicdevelopment-evidence/docview/305007369/se-2?accountid=17242 ABI/INFORM Collection; ProQuest Dissertations \& Theses Global database. (3174735)

Adera, E. O., Waema, T. M., \& May, J. D. (2014). ICT pathways to poverty reduction: Empirical evidence from East and Southern Africa: IDRC.

Adeya, C. N. (2002). ICTs and poverty: A literature review. Ottawa, IDRC.

Bank Indonesia. (2021). Statistik Ekonomi dan Keuangan Daerah (SEKDA). Retrieved from https://www.bi.go.id/id/statistik/ekonomi-keuangan/sekda/Default.aspx

Beck, T., Demirguc-Kunt, A., \& Levine, R. (2005). SMEs, Growth, and Poverty: CrossCountry Evidence. Journal of Economic Growth, 10(3), 199-229. Retrieved from http://remote-lib.ui.ac.id:2100/stable/40216076 
Botelho, A. J., \& da Silva Alves, A. (2007). Mobile use/adoption by micro, small and medium enterprises in Latin America and the Caribbean. Background paper for "Mobile Opportunities: Poverty and Telephony Access in Latin America and the Caribbean" project. Lima: DIRSI and IDRC.

Brynjolfsson, E., \& McAfee, A. (2014). The second machine age: Work, progress, and prosperity in a time of brilliant technologies: WW Norton \& Company.

Cameron, A., \& Trivedi, P. (2019). Microeconometrics. Cambridge (UK) [etc.]: Cambridge University Press.

Cardona, M., Kretschmer, T., \& Strobel, T. (2013). ICT and productivity: conclusions from the empirical literature. Information economics and policy, 25(3), 109-125. doi:10.1016/j.infoecopol.2012.12.002

Carroll, G. R. (1993). A Sociological View on Why Firms Differ. Strategic management journal, 14(4), 237-249. doi:10.1002/smj.4250140402

Chacko, J. G., \& Harris, G. (2006). Information and communication technology and small, medium, and micro enterprises in Asia-Pacific-size does matter. Information Technology for Development, 12(2), 175-177. doi:10.1002/itdj.20034

Chew, H. E., Ilavarasan, P. V., \& Levy, M. R. (2010). The Economic Impact of Information and Communication Technologies (ICTs) on Microenterprises in the Context of Development. The Electronic Journal of Information Systems in Developing Countries, 44(1), 1-19. doi:https:/ / doi.org/10.1002/j.1681-4835.2010.tb00316.x

Dedrick, J., Kraemer, K. L., \& Shih, E. (2013). Information Technology and Productivity in Developed and Developing Countries. Journal of Management Information Systems, 30(1), 97-122. doi:10.2753/MIS0742-1222300103

Dell'Anno, R., \& Solomon, H. O. (2014). Informality, Inequality, and ICT in Transition Economies. Eastern European Economics, 52(5), 3-31. doi:10.1080/001287755.2014.1004264

Donner, J., \& Escobari, M. X. (2010). A review of evidence on mobile use by micro and small enterprises in developing countries. Journal of International Development, 22(5), 641658. doi:https://doi.org/10.1002/jid.1717

Duncombe, R. (2007). Using the Livelihoods Framework to Analyze ICT Applications for Poverty Reduction through Microenterprise. Information Technologies \& International Development, 3(3), 81-100. doi:10.1162/itid.2007.3.3.81

Duncombe, R., \& Heeks, R. (2002). Enterprise across the digital divide: information systems and rural microenterprise in Botswana. Journal of International Development, 14(1), 61-74. doi:10.1002/jid.869

Heeks, R. (2010). Do information and communication technologies (ICTs) contribute to development? Journal of International Development, 22(5), 625-640. doi:10.1002/jid.1716

Indonesia Statistics Buraeu. (2019). Potensi Peningkatan Kinerja Usaha Mikro Kecil. Jakarta: BPS Indonesia. Retrieved from https://www.bps.go.id/publication/2019/03/05/ 
66912048b475b142057f40be/analisis-hasil-se2016-lanjutan-potensi-peningkatankinerja-usaha-mikro-kecil.html

International Finance Corporation. (2016). UKM yang dimiliki Wanita di Indonesia: Kesempatan Emas untuk Institusi Keuangan Lokal. Retrieved from https://www.ifc.org/wps/wcm/connect/8496be45-d4d4-4480-a9f5-

49c073294b26/SME+Indonesia_Final_Ind.pdf?MOD=AJPERES\&CVID=lj81Vuj

Ismail, R., Jeffery, R., \& Van Belle, J.-P. (2011). Using ICT as a value adding tool in South African SMEs. Journal of African Research in Business \& Technology, 2011, 1-12.

Jayaratne, J., \& Strahan, P. E. (1996). The finance-growth nexus: Evidence from bank branch deregulation. The Quarterly Journal of Economics, 111(3), 639-670. https:// doi.org/10.2307/2946668

Jorgenson, D. W., \& Vu, K. M. (2016). The ICT revolution, world economic growth, and policy issues. Telecommunications policy, 40 (5), 383-397. doi:10.1016/j.telpol.2016.01.002

Lee, S., Xiang, J. Y., \& Kim, J. K. (2011). Information technology and productivity: Empirical evidence from the chinese electronics industry. Information \& Management, 48(2), 79-87. https:/ / doi.org/10.1016/j.im.2011.01.003

Marker, P., McNamara, K., \& Wallace, L. (2002). The significance of information and communication technologies for reducing poverty. London, UK: DFID.

Mauri, A. J., \& Michaels, M. P. (1998). Firm and Industry Effects Within Strategic Management: an Empirical Examination. Strategic Management Journal (1986-1998), 19(3), 211. Retrieved from https://search.proquest.com/scholarly-journals/firmindustry-effects-within-strategic-management/docview/231094907/se2 ? accountid $=17242$

Meryana,E.(2012). Megapolitan Kompas. Retrieved from https://megapolitan.kompas.com/read/2012/03/28/11481062/cides.hadapi.kenai kan.harga.bbm.umkm.sudah.teruji

Mpogele, H., Usanga, H., \& Tedre, M. (2008). Mobile phones and poverty alleviation: a survey study in rural Tanzania.

Niebel, T. (2018). ICT and economic growth - comparing developing, emerging and developed countries. World Development, 104, 197-211. https:// doi.org/10.1016/j.worlddev.2017.11.024

Nielinger, O. (2003). Fact Sheet: ICT-utilisation of small and medium enterprises (SME) in Tanzania. ourtanzania. com.

Organisation for Economic Co-operation and Development. (2008). Handbook on Constructing Composite Indicators. Paris: Organisation for Economic Co-operation and Development.

Paunov, C., \& Rollo, V. (2016). Has the Internet Fostered Inclusive Innovation in the Developing World? World development, 78, 587-609. doi:10.1016/j.worlddev.2015.10.029 
Peng, G., Wang, Y., \& Han, G. (2018). Information technology and employment: The impact of job tasks and worker skills. Journal of Industrial Relations, 60(2), 201-223. doi:10.1177/0022185617741924

Stanley, T. D., Doucouliagos, H., \& Steel, P. (2018). Does ICT Generate Economic Growth? a Meta-Regression Analysis: Does ICT Generate Economic Growth? Journal of economic surveys, 32(3), 705-726. doi:10.1111/joes.12211

Tambunan, t. (2007). Entrepreneurship Development: SMES in Indonesia. Journal of Developmental Entrepreneurship, 12(01), 95-118. doi:10.1142/s1084946707000575

Van Roy, V., Vértesy, D., \& Vivarelli, M. (2018). Technology and employment: Mass unemployment or job creation? Empirical evidence from European patenting firms. Research Policy, 47(9), 1762-1776. doi:https:/ / doi.org/10.1016/j.respol.2018.06.008

World Bank. (2016). World development report 2016: Digital dividends. In: The World Bank. 